\title{
PENDIDIKAN KONSUMEN GENERASI Y: PENGARUH ETHNOSENTRISME, HEDONISME, DAN KELOMPOK ACUAN TERHADAP PREFERENSI DAN PERILAKU PEMBELIAN BUAH LOKAL
}

\author{
Putri Claristha Violetta*), Hartoyo, Nimmi Zulbainarni \\ Manajemen dan Bisnis, Sekolah Bisnis, Institut Pertanian Bogor, Jl Raya Pajajaran, \\ Bogor 16151, Indonesia \\ *)Email: claristhav@gmail.com
}

\begin{abstract}
Abstrak
Penelitian ini bertujuan untuk menganalisis pengaruh ethnosentrisme, hedonisme, dan kelompok acuan terhadap preferensi dan perilaku pembelian buah lokal konsumen generasi Y. Penelitian ini merupakan penelitian deskriptif dengan metode survei menggunakan kuisioner. Pengambilan contoh penelitian menggunakan non probability sampling dan jumlah contoh yang terlibat adalah 200 orang mahasiswa Sekolah Bisnis dan Fakultas Ekonomi dan Manajemen Institut Pertanian Bogor yang telah dibagi secara proporsional dengan menggunakan sample fraction sesuai dengan jumlah mahasiswa di masing-masing jurusan/program studi. Analisis data dilakukan dengan menggunakan Structural Equation Modelling (SEM). Hasil analisis menunjukkan bahwa ethnosentrisme berpengaruh signifikan positif dan hedonisme berpengaruh signifikan negatif terhadap preferensi konsumen generasi $\mathrm{Y}$, preferensi konsumen berpengaruh signifikan positif dan hedonisme berpengaruh signifikan negatif terhadap perilaku pembelian buah lokal generasi Y. Kelompok acuan berpengaruh positif tetapi tidak signifikan terhadap preferensi dan perilaku pembelian buah lokal konsumen generasi Y. Preferensi dan perilaku pembelian buah lokal konsumen generasi $Y$ dapat ditingkatkan dengan cara meningkatkan ethnosentrisme dan menekan hedonisme konsumen generasi $\mathrm{Y}$.
\end{abstract}

Kata kunci : ethnosentrisme, generasi $\mathrm{Y}$, hedonisme, kelompok acuan, perilaku pembelian

\section{Generation Y Consumer Education: The Influence Of Ethnocentrism, Hedonism, And Reference Group Toward Preference And Purchasing Behaviour On Local Fruits}

\begin{abstract}
The purpose of this research is to examine the influence of ethnocentrism, hedonism, and reference groups to the preferences and purchasing behaviour of local fruit by generation $Y$. This research is a descriptive research with survey method using questionnaire. The sampling of this research used non-probability sampling and the number of respondents was 200 students from School of Business and Faculty of Economic and Management Bogor Agricultural University that was divided proportionally based on the sample fraction according to the population of each department at the Faculty. The data analysis used Structural Equation Modelling (SEM). The result showed that ethnocentrism had positively significant influence and hedonism had negatively significant influence on generation Y's preference, consumer preferences had positively significant influence and hedonism had negatively significant influence on generation Y's purchasing behaviour of local fruit. Reference group had positively but not significant influence on generation Y's preference and purchasing behaviour of local fruit. Generation Y's preference and purchasing behaviour of local fruits can be improved by increasing the ethnocentirsm and decreasing the hedonism of generation $\mathrm{Y}$ consumer.
\end{abstract}

Keywords : ethnocentrism, generation $\mathrm{Y}$, hedonism, purchasing behaviour, reference groups.

\section{PENDAHULUAN}

Kesadaran masyarakat untuk mengonsumsi buah-buahan mulai meningkat. Berdasarkan hasil dari Susenas oleh Badan Pusat Statistik pada tahun 2013 hingga 2016 menunjukkan bahwa terdapat peningkatan rata-rata pengeluaran per kapita untuk konsumsi buahbuahan dari tahun 2013 yang semula sebesar
Rp16.379,00 pada tahun 2014 meningkat menjadi Rp19.234,00 kemudian pada tahun 2015 meningkat menjadi RP19.600,00 dan pada tahun 2016 rata-rata konsumsi buah per kapita per bulan mencapai Rp20.400,00. Peningkatan rata-rata pengeluaran per kapita untuk konsumsi buah juga berbanding lurus dengan peningkatan volume buah impor yang masuk ke Indonesia (BPS, 2016). 
Data dari Direktorat Jenderal Hortikultura menunjukkan bahwa buah impor yang masuk ke Indonesia pada November 2016 adalah sebanyak $86.939 .945,00 \mathrm{~kg}$ atau senilai US\$109.657.839,00. Berdasarkan data tersebut diketahui bahwa buah yang paling banyak diimpor oleh Indonesia adalah jeruk, apel, pir, anggur, dan kelengkeng. Sementara itu, buah-buahan seperti jeruk, apel, anggur dan kelengkeng juga diproduksi oleh petani lokal Indonesia. Adanya produksi buah lokal seharusnya dapat membuat volume buah impor di pasar berkurang dari tahun ke tahun. Peningkatan volume impor buah pada jenisjenis buah yang juga diproduksi secara lokal ini mengindikasikan bahwa konsumen buah di Indonesia lebih memilih untuk mengonsumsi buah impor dibandingkan buah lokal.

Pemberlakuan kesepakatan Masyarakat Ekonomi ASEAN (MEA) telah memasuki tahun kedua. Adanya MEA memberikan berbagai peluang dan juga tantangan bagi masyarakat Indonesia. Tantangan tersebut termasuk masuknya berbagai produk impor ke pasar Indonesia, termasuk produk buah impor. Salah satu isi pilar dari MEA adalah kawasan terintegrasi dengan ekonomi dunia yang diyakini dapat memberikan manfaat nyata bagi seluruh elemen masyarakat (Amri, 2015). Malau (2014) menyatakan MEA memberikan jaminan kelancaran arus barang yang diperdagangkan, juga memberikan kemudahan bagi konsumen untuk mengonsumsi suatu produk sesuai dengan kebutuhan dan kemampuannya dengan berbagai alternatif yang ada. Sementara hasil penelitian Benny dan Abdullah (2011) menggambarkan sekitar 12 persen responden menyatakan bahwa masih belum mengetahui secara detail mengenai komunitas ASEAN dan konsep pembentukannya. Kondisi ini yang membuat perekonomian kurang stabil dan belum memiliki kesiapan menghadapi MEA disebabkan kurangnya informasi dan pengetahuan dari konsumen. Menurut Swajaya (2015) salah satu cara mempersiapkan MEA dengan memberikan kegiatan sosialisasi, termasuk melalui iklan televisi dan media sosial sehingga dapat meningkatkan daya saing dan kualitas kelembagaan serta sumber daya manusia. Selain itu, pemerintah dan produsen memiliki peran penting untuk meningkatkan pemberdayaan konsumen. Konsumen yang berdaya harus percaya diri, knowledgeable dan merasa dilindungi, serta cenderung untuk mengambil keputusan dengan memahami preferensinya, pilihan yang tersedia dan haknya, serta cara mengajukan complain dan mencari penyelesaian jika haknya dilanggar (European Commission, 2011).

Masalah perlindungan konsumen di Indonesia masih belum mendapatkan banyak perhatian. Penegakan perlindungan konsumen dikatakan berhasil jika setiap konsumen telah sanggup melindungi diri sendiri dari segala macam hal yang merugikannya (Simanjutak, 2014). Indeks Keberdayaan Konsumen (IKK) tahun 2016 sebesar 30,86 yang berada pada level paham, artinya konsumen Indonesia sudah memahami dan mengenali hak dan kewajibannya namun belum sepnuhnya mampu menggunakannya untuk menentukan pilihan konsumsinya serta belum mampu memperjuangkan haknya sebagai konsumen (Bappenas, 2017). Menurut UU No 8 Tahun 1999 tentang Perlindungan Konsumen Pasal 1 menyebutkan bahwa segala upaya yang menjamin adanya kepastian hukum untuk memberi perlindungan kepada konsumen. Adanya era globalisasi menuntut konsumen untuk dapat menetapkan pilihan yang cerdas dalam mengonsumsi barang dan jasa. Konsumen Indonesia saat ini telah menjadi target pasar dengan orientasi produk impor sehingga bentuk edukasi yang dilakukan oleh pemerintah adalah dengan cara mentransformasikan konsumen Indonesia menjadi konsumen cerdas, mandiri, dan cinta produk Indonesia. Menurut Mendag (2013) menyatakan bahwa masyarakat Indonesia harus menyadari bahwa mengonsumsi produk lokal adalah salah satu kunci pertumbuhan ekonomi yang akan membawa kesejahteraan rakyat Indonesia. Konsumen Indonesia terdiri dari berbagai macam segmen pasar, dan tentunya dibutuhkan strategi-strategi agar konsumen di setiap segmen pasar dapat bertransformasi menjadi konsumen yang berdaya.

Selama beberapa tahun generasi digunakan sebagai kriteria segmen pasar oleh para praktisi maupun peneliti. Teori generasi mengemukakan bahwa kelompok generasi berbagi pengalaman hidup yang menyebabkan mereka memiliki sikap dan kepercayaan yang sama (Meriac et al., 2010). Setiap generasi memiliki harapan, pengalaman, sejarah, gaya hidup, nilai, dan demografi yang memengaruhi perilaku pembelian mereka (William \& Page, 2011). Empat generasi yang diidentifikasi disebut dengan generasi Traditionalist (19301945), Baby Boomers (1946-1964), generasi X (1965-1981), dan generasi $Y$ yang juga disebut sebagai generasi Millenials (1982-2000) (Gursoy et al., 2008). Generasi $Y$ adalah generasi terbesar saat ini dan telah menjadi konsumen pada usia yang lebih muda 
dibanding generasi sebelumnya (Pantecost \& Andrew, 2010). Konsumen generasi $Y$ menjadi segmen yang sangat penting karena populasinya yang besar di masyarakat, jumlah pengeluaran dan potensi daya beli di saat ini dan masa mendatang (Lazarevic, 2012). Hasil penelitian Eastman dan Liu (2012) menunjukkan bahwa rata-rata level status konsumsi terbesar terdapat pada generasi $\mathrm{Y}$ dibandingkan dengan generasi pendahulu maupun generasi sesudahnya. Tidak seperti generasi sebelumnya, generasi $\mathrm{Y}$ telah menyesuaikan diri ke dalam lingkungan yang menyediakan kemungkinan dan alasan lebih untuk berbelanja dibandingkan sebelumnya (Bakewell \& Mitchel, 2003).

Perilaku konsumsi dan belanja, generasi $Y$ ditandai dengan sifat yang spesifik seperti pengambilan keputusan belanja yang penuh emosi, terbuka akan inovasi, lebih cepat mengadopsi produk, high social influence, menggunakan pendekatan materialistik, dan memiliki kecenderungan yang kuat dalam membeli merek dengan identitas tertentu. Generasi $Y$ lebih terpusat pada kepuasan hedonik dan pengakuan status yang menempatkan pertimbangan usaha dan emosi yang tinggi dalam pembelian (Edu, Preda, \& Negrice, 2014). Beragam kemungkinan dan alasan belanja yang dialami oleh generasi $Y$ menyebabkan banyak konsumen yang berpindah dari berbelanja untuk kebutuhan objektif dan terukur menjadi belanja yang juga mempertimbangkan komponen subjektif dan hedonik (Maehle et al., 2015). Saat ini, pasar juga menawarkan produk yang mengurangi faktor kebutuhan dan meningkatkan faktor hedonik sehingga konsumen memutuskan untuk menggunakan produk tersebut sebagai alasan untuk mendapatkan kesenangan (Filho \& Dholakia, 2013). Hedonic shopping merupakan suatu keinginan seseorang untuk mendapatkan suatu kesenangan bagi dirinya sendiri yang dapat dipenuhi dengan cara menghabiskan waktu untuk mengunjungi pusat perbelanjaan atau mall, menikmati suasana atau atmosfer yang ada di pusat perbelanjaan itu sendiri meski tidak membeli atau hanya melihat-lihat saja (Japarianto, 2011). Penelitian oleh Aertsens et al. (2009) menyatakan bahwa hedonisme adalah salah satu faktor motivasi konsumen dalam mengonsumsi produk makanan.

Perbedaan karakteristik generasi $Y$ berkaitan dengan pergeseran nilai yang terjadi pada generasi $Y$ dari generasi pendahulunya (Hyllegard et al., 2011). Penelitian oleh Loroz dan Hegelson (2013) menunjukkan bahwa generasi $\mathrm{Y}$ memiliki nilai materialistik yang lebih tinggi dan rasa empati yang lebih rendah dibandingkan pendahulunya. Nilai merupakan segala sesuatu yang dianggap penting oleh seseorang atau suatu masyarakat (Sumarwan, 2014). Salah satu cara mengukur nilai adalah dengan merepresentasikan ethnosentrisme. Ethnosentrisme konsumen adalah kepercayaan bahwa membeli produk buatan asing adalah tindakan yang tidak pantas, bahkan mungkin tidak bermoral, karena akan merugikan ekonomi domestik (Rhiney, 2011). Ethnosentrisme merupakan kepercayaan yang dapat memengaruhi preferensi konsumen terhadap produk lokal (Hsu \& Nuen, 2008). Ethnosentrisme konsumen akan memengaruhi keputusan pembelian konsumen untuk produk dalam negeri dan luar negeri dari persepsi kualitas produk secara langsung maupun tidak langsung (Li et al., 2012). Penelitian mengenai ethnosentrisme pernah dilakukan terhadap ibu rumah tangga di Serang oleh Sukmaningtyas dan Hartoyo (2013) yang menunjukkan bahwa tingkat ethnosentrisme ibu rumah tangga masih rendah atau dapat dikatakan masih sedikit ibu rumah tangga yang memiliki kepercayaan tinggi atau memilih produk lokal. Penelitian lain mengenai ethnosentrisme juga dilakukan oleh Anggasari et al. (2013) yang menunjukkan bahwa ethnosentrisme memiliki hubungan positif dan signifikan terhadap sikap, preferensi, dan perilaku pembelian. Penelitian oleh Bianchi dan Mortimer (2015) menunjukkan bahwa ethnosentrisme berpengaruh positif dan signifikan terhadap konsumsi produk makanan lokal. Penelitian oleh Qing et al. (2012) menunjukkan bahwa ethnosentrisme konsumen memiliki peran penting dalam membentuk perilaku pembelian konsumen terhadap produk buah lokal pada masyarakat di negara Cina. Shrimp dan Sharma (1987) menyatakan bahwa konsumen yang mengonsumsi buah lokal merupakan konsumen yang memiliki tingkat ethnosentrisme yang tinggi sedangkan konsumen yang mengonsumsi buah impor merupakan suatu yang salah karena dapat merugikan negara.

Generasi $Y$ dikatakan lebih terhubung dan terinteraksi dibandingkan generasi sebelumnya (Edu, Preda, \& Negrice, 2014). Konsumen generasi $\mathrm{Y}$ juga merupakan masyarakat dengan kesadaran diri tinggi yang cenderung membuat keputusan berdasarkan pengaruh dan pendapat rekan mereka (Fernandez, 2009). Hal ini menyebabkan generasi $Y$ memiliki berbagai kelompok acuan bila dibandingkan dengan generasi sebelumya. Kelompok acuan adalah seorang individu atau 
sekelompok orang yang secara nyata memengaruhi perilaku seseorang (Sumarwan, 2014). Kelompok acuan seringkali memengaruhi seseorang dalam melakukan pembelian. Kelompok acuan juga menjadi wadah bertukar informasi. Konsumen dapat mengubah kepercayaan mereka terhadap suatu merek berdasarkan pada sellf brand connection dan pengaruh dari kelompok acuan (Hammerl et al., 2016). Orth dan Kayle (2008) menunjukkan adanya keterkaitan antara kelompok acuan dengan nilai pribadi dan identitas sosial. Informasi dan ekspresi nilai yang dimiliki oleh kelompok acuan berpengaruh positif terhadap niat beli dan keputusan pembelian kembali (Lin \& Chen, 2009). Penelitian oleh Anoraga dan Iriani (2013) mengenai kelompok acuan menunjukkan bahwa terdapat hubungan positif antara gaya hidup dan kelompok acuan terhadap keputusan pembelian secara simultan.

Perbedaan karakteristik generasi $\mathrm{Y}$ dengan generasi sebelumnya dapat memberikan dampak yang signifikan pada perilaku pembelian dan konsumsi bagi berbagai pangsa pasar termasuk pasar buah-buahan. Penelitian ini menganalisis pengaruh preferensi dan perilaku pembelian konsumen generasi $Y$ terhadap buah lokal. Preferensi konsumen adalah tingkat penerimaan konsumen terhadap suatu produk tertentu yang dipengaruhi oleh perilaku konsumen dan persepsi konsumen terhadap produk tersebut (Sumarwan, 2014). Perilaku konsumen generasi $Y$ perlu diketahui karena generasi $Y$ saat ini telah menjadi konsumen yang paling banyak berdasarkan jumlahnya di masyarakat dan akan terus menjadi konsumen paling banyak dalam jangka panjang. Selain itu generasi $Y$ juga lebih konsumtif dibandingkan generasi pendahulunya. Perilaku konsumen didefinisikan sebagai perilaku yang diperlihatkan konsumen dalam mencari, membeli, menggunakan mengevaluasi, dan menghabiskan produk dan jasa yang mereka harapkan akan memuaskan kebutuhan mereka (Schiffman \& Kanuk, 2010).

Berdasarkan paparan di atas maka dibentuk tujuh hipotesis yang bertujuan untuk menganalisis pengaruh ethnosentrisme, hedonisme, dan kelompok acuan pada preferensi dan perilaku pembelian buah lokal konsumen generasi $Y$. Hipotesis tersebut antara lain: (i) ethnosentrisme berpengaruh positif terhadap preferensi konsumen generasi Y dalam mengonsumsi buah lokal; (ii) hedonisme berpengaruh negatif terhadap preferensi konsumen generasi $\mathrm{Y}$ dalam mengonsumsi buah lokal; (iii) kelompok acuan berpengaruh positif terhadap preferensi konsumen generasi $Y$ terhadap buah lokal; (iv) ethnosentrisme berpengaruh positif terhadap perilaku pembelian buah lokal konsumen generasi $\mathrm{Y}$; $(\mathrm{v})$ hedonisme berpengaruh negatif terhadap perilaku pembelian buah lokal konsumen generasi Y; (vi) kelompok acuan berpengaruh positif terhadap perilaku pembelian buah lokal konsumen generasi $\mathrm{Y}$; dan (vii) preferensi konsumen berpengaruh positif terhadap perilaku pembelian buah lokal konsumen generasi $\mathrm{Y}$.

\section{METODE}

Penelitian ini merupakan penelitian deksriptif yang dilakukan dengan metode survei. Metode survei dilakukan melalui wawancara dengan alat bantu kuisioner yang diberikan langsung kepada responden. Metode pengambilan contoh dilakukan dengan teknik nonprobability sampling melalui pendekatan purposive sampling dengan menentukan tempat pengambilan responden yaitu Sekolah Bisnis dan Fakultas Ekonomi dan Manajemen Institut Pertanian Bogor dan pengambilan responden secara convenience sampling, yaitu responden yang dijumpai pada lokasi penelitian dan menyatakan bersedia menjadi partisipan penelitian ketika diminta oleh peneliti.

Responden dalam penelitian ini adalah konsumen buah-buahan dengan kriteria pernah membeli buah-buahan impor maupun lokal dalam tiga bulan terakhir dan merupakan mahasiswa Sekolah Bisnis dan Fakultas Ekonomi dan Manajemen Institut Pertanian Bogor dengan rentang usia 18 sampai 22 tahun. Mahasiswa dipilih sebagai contoh mewakili generasi $Y$ dikarenakan mahasiswa adalah salah satu pembawa perubahan terbesar sehingga dapat digunakan sebagai roda revolusi mental bangsa. Jumlah contoh dalam penelitian ini dibatasi berdasarkan persyaratan analisis Structural Equation Modelling (SEM) yakni sebanyak 200 responden yang telah dibagi secara proporsional dengan menggunakan sample fraction sesuai dengan jumlah mahasiswa di masing-masing jurusan/program studi.

Variabel yang digunakan dalam penelitian ini adalah variabel deskriptif, variabel independen, dan variabel dependen. Variabel deskriptif adalah variabel yang digunakan untuk menggambarkan karakteristik responden meliputi jenis kelamin, usia, rata-rata pengeluaran per bulan, suku bangsa orang 
tua, karakteristik generasi $\mathrm{Y}$, dan perilaku konsumsi buah responden. Karakteristik generasi $Y$ responden diambil berdasarkan usia aktif belanja, pembelanjaan tidak terencana, kemudahan mengadopsi produk baru, pengaruh kelompok acuan, dan pengaruh merk dalam pembelian. Perilaku konsumsi buah meliputi jenis buah yang sering dikonsumsi, intensitas konsumsi buah, pengeluaran untuk konsumsi buah per minggu, dan kesukaan terhadap jenis buah. Variabel independen pada penelitian ini adalah ethnosentrisme, hedonisme, dan kelompok acuan, sedangkan variabel dependennya adalah preferensi dan perilaku pembelian buah lokal konsumen generasi Y. Variabel independen dan dependen dibentuk oleh variabel indikator yang diukur menggunakan skala Likert 1 sampai 5 . Angka 1 menunjukkan sangat tidak setuju dan angka 5 menunjukkan sangat setuju.

Tingkat ethnosentrisme diukur menggunakan skala CETSCALE yang dibuat oleh Shrimp dan Sharma (1987) dan telah digunakan pada banyak penelitian mengenai ethnosentrisme. Tingkat ethnosentrisme responden pada penelitian ini dibagi menjadi tiga kategori yaitu rendah (32-45), sedang (46-59), dan tinggi (6073). Indikator hedonisme responden mengacu pada penelitian Satriawan, Hartoyo dan Yuliati (2015) sehingga diperoleh empat indikator hedonisme responden terhadap buah lokal yang menunjukkan bahwa membeli dan mengonsumsi buah impor adalah kegiatan yang menyenangkan, memberikan semangat, dan rasa bangga. Kelompok acuan responden diukur menggunakan lima indikator yang mengacu lima dimensi kelompok acuan menurut Engel, Blackwell, dan Miniard (1994) yaitu pengetahuan kelompok acuan mengenai produk, kredibilitas kelompok acuan, pengalaman dari kelompok acuan, keaktifan kelompok acuan, dan daya tarik kelompok acuan. Preferensi konsumen diukur menggunakan tiga indikator yang menunjukkan kesukaan responden terhadap buah lokal dibandingkan buah impor, sedangkan perilaku pembelian diukur menggunakan dua indikator yakni intensitas dan volume pembelian buah lokal dibandingkan dengan buah impor (Anggasari et al., 2013).

Data dari variabel demografi kemudian diolah secara deskriptif untuk melihat karakteristik responden yang digunakan dalam penelitian ini. Data yang diperoleh dari variabel independen dan variabel dependen diolah menggunakan Structural Equation Modelling
(SEM) untuk melihat bagaimana pengaruh ethosentrisme, hedonisme, dan kelompok acuan terhadap preferensi dan perilaku pembelian buah lokal konsumen generasi $Y$.

\section{HASIL}

\section{Karakteristik Responden}

Responden yang terlibat dalam penelitian ini berusia antara 18 sampai dengan 22 tahun dan sebagian besar responden berusia 20 tahun (42,5\%) dengan hampir tiga perempatnya berjenis kelamin perempuan $(69,0 \%)$. Rata-rata pengeluaran rumah tangga responden berada pada rentang $\mathrm{Rp} 800.000,00$ -Rp1.500.000,00 per bulan yakni sebesar 51,0 persen dari total responden. Hasil sebaran menunjukkan bahwa responden yang memiliki pengeluaran rumah tangga per bulan kurang dari Rp800.000,00 sebanyak (19,0\%), responden yang memiliki pengeluaran rumah tangga per bulan pada rentang Rp1.500.000,00 - Rp2.000.000,00 sebanyak $(18,5 \%)$, dan responden yang memiliki pengeluaran rumah tangga di atas Rp2.000.000,00 sebanyak $(11,5 \%)$.

Suku bangsa dalam penelitian ini dikategorikan menjadi lima yaitu suku bangsa Jawa, Sunda, Betawi, Tionghoa, dan suku bangsa lainnya. Hasil penelitian menunjukkan bahwa ebih dari separuh $(54,0 \%)$ asal suku bangsa orang tua responden berasal dari suku bangsa Jawa dan ibu responden berasal dari suku bangsa Jawa $(50,0 \%)$. Kategori suku bangsa lainnya menempati urutan terbanyak kedua setelah suku bangsa Jawa. Suku bangsa lainnya ayah sebesar $(29,0 \%)$ dan kategori suku bangsa lainnya ibu sebesar $(27,0 \%)$. Suku bangsa yang termasuk dalam kategori lainnya adalah suku bangsa Madura, Batak, Dayak, dan Minang. Suku bangsa Batak dan Minang merupakan suku bangsa yang banyak ditemui dalam kategori suku bangsa lainnya. Hal ini dapat disebabkan karena mahasiswa yang menjadi responden penelitian merupakan mahasiswa yang berasal dari berbagai daerah di seluruh wilayah Indonesia. Sisanya adalah suku bangsa Sunda, Betawi, dan Tionghoa. Hasil uji chi-square menunjukkan bahwa tidak terdapat hubungan antara asal suku bangsa orang tua dengan tingkat ethnosentrisme yang dimiliki oleh responden.

\section{Perilaku terkait Karakteristik Generasi Y}

Usia aktif belanja responden dikelompokkan ke dalam empat kategori yaitu sejak sebelum berusia 14 tahun, saat berusia 14-16 tahun, 
saat berusia 17-19 tahun, dan saat berusia lebih dari 19 tahun. Responden pada penelitian ini paling banyak mulai aktif berbelanja pada usia 17-19 tahun (52,0\%), kemudian pada usia 14-16 tahun (21,5\%), kurang dari 14 tahun $(16,0 \%)$, dan lebih dari 20 tahun $(10,0 \%)$. Hampir seluruh responden pada penelitian ini pernah melakukan pembelanjaan tidak terencana $(99,0 \%)$, sangat sedikit responden yang tidak pernah melakukan pembelanjaan tidak terencana $(1,0 \%)$. Dalam hal kemudahan mengadopsi produk baru, responden mudah mengadopsi produk baru berdasarkan pertimbangan $(70,5 \%)$, responden sangat mudah mengadopsi produk baru $(19,0 \%)$, dan responden tidak mudah mengadopsi produk baru (10,5\%). Responden terkadang terpengaruh oleh kelompok acuan dalam melakukan pembelian $(60,5 \%)$, terdapat pula responden yang selalu terpengaruh kelompok acuan $(30,5 \%)$, dan yang tidak pernah terpengaruh oleh kelompok acuan (9,0\%). Responden pada penelitian ini melakukan pembelian berdasarkan merk barang yang dibeli $(67,0 \%)$, responden terkadang melakukan pembelian berdasarkan merk $(23,0 \%)$, dan responden tidak peduli terhadap merk barang yang mereka beli $(10,0 \%)$.

Berdasarkan penelitian mengenai karakteristik generasi $Y$ diketahui bahwa responden pada penelitian ini memiliki perilaku yang sesuai dengan karakteristik generasi $\mathrm{Y}$, yakni telah menjadi konsumen di usia yang lebih muda dibandingkan generasi sebelumnya, sering melakukan pembelanjaan tidak terencana, mudah mengadopsi produk baru, dapat terpengaruh oleh kelompok acuan, dan memiliki kecendrungan untuk mengonsumsi barang dengan merk tertentu.

\section{Perilaku Konsumsi Buah}

Secara umum buah yang sering dikonsumsi oleh responden adalah buah yang terdapat pada kategori lainnya. Buah-buahan tersebut antara lain pisang, melon, mangga, dan jambu biji. Buah lokal yang paling banyak dikonsumsi oleh responden adalah buah pisang. Hal ini dapat dikarenakan buah pisang lebih mudah ditemui dan memiliki harga yang relatif lebih murah dibandingkan buah-buahan lokal lainnya seperti apel, jeruk, anggur, dan kelengkeng. Sementara itu, buah impor yang paling banyak dikonsumsi oleh responden adalah buah apel impor. Hal ini sesuai dengan preferensi responden yang sebagian besar lebih menyukai apel impor dibandingkan apel lokal. Responden lebih menyukai apel dan anggur impor sedangkan untuk jenis buah jeruk dan kelengkeng sebagian besar responden lebih menyukai jeruk dan kelengkeng lokal.

Rata-rata intensitas konsumsi buah responden dibagi menjadi lima kategori antara lain setiap hari, 2-3 kali per minggu, satu kali per minggu, 2-3 kali per bulan, dan satu kali per bulan. Hasil penelitian menunjukkan bahwa responden mengonsumsi buah dengan intensitas 2-3 kali per minggu (42,5\%) dan hanya $8,0 \%$ responden yang mengonsumsi buah setiap hari. Sementara itu, pengeluaran responden untuk konsumsi buah dalam seminggu dibagi ke dalam empat kategori yaitu lebih besar dari Rp100.000,00; Rp60.000,00 sampai Rp100.000,00; Rp20.000,00 sampai Rp59.000,00; dan lebih kecil dari Rp20.000,00. Pengeluaran responden untuk konsumsi buah tergolong kecil dikarenakan lebih dari separuh responden tidak mengeluarkan lebih dari Rp60.000,00 per minggu untuk konsumsi buah. Hanya 9,0 persen dari responden yang memiliki pengeluaran besar untuk konsumsi buah dalam seminggu.

\section{Tingkat Ethnosentrisme}

Hasil penelitian menunjukkan hampir dua pertiga responden $(67,0 \%)$ memiliki tingkat ethnosentrisme sedang. Hal ini mengindikasikan bahwa responden cenderung membeli dan mengonsumsi buah lokal, tetapi responden juga bersikap sangat terbuka terhadap buah impor. Sebaran data responden menunjukkan bahwa ada reponden yang memiliki tingkat ethnosentrisme rendah sebanyak $(23,0 \%)$ dan responden yang memiliki tingkat ethnosentrisme tinggi sebanyak $(10,0 \%)$.

Responden yang memiliki tingkat ethnosentrisme tinggi memiliki ciri-ciri selalu membeli buah lokal dibandingkan buah impor dan menjadikan buah lokal pilihan utama karena tidak ingin membiarkan negara lain memperoleh keuntungan dan tetap membeli buah lokal walaupun harganya lebih mahal demi mendukung produk lokal. Ciri-ciri responden yang memiliki tingkat ethnosentrisme rendah adalah tidak merasa bertanggung jawab terhadap kehidupan petani lokal, tidak akan membeli buah lokal apabila harganya lebih mahal, tidak menganggap bahwa produksi dalam negeri adalah yang terbaik. Responden dengan tingkat ethnosentrisme rendah juga memiliki pengeluaran yang kecil untuk konsumsi buah yakni kurang dari Rp20.000,00 per minggu. 
Tabel 1 Analisis model pengukuran

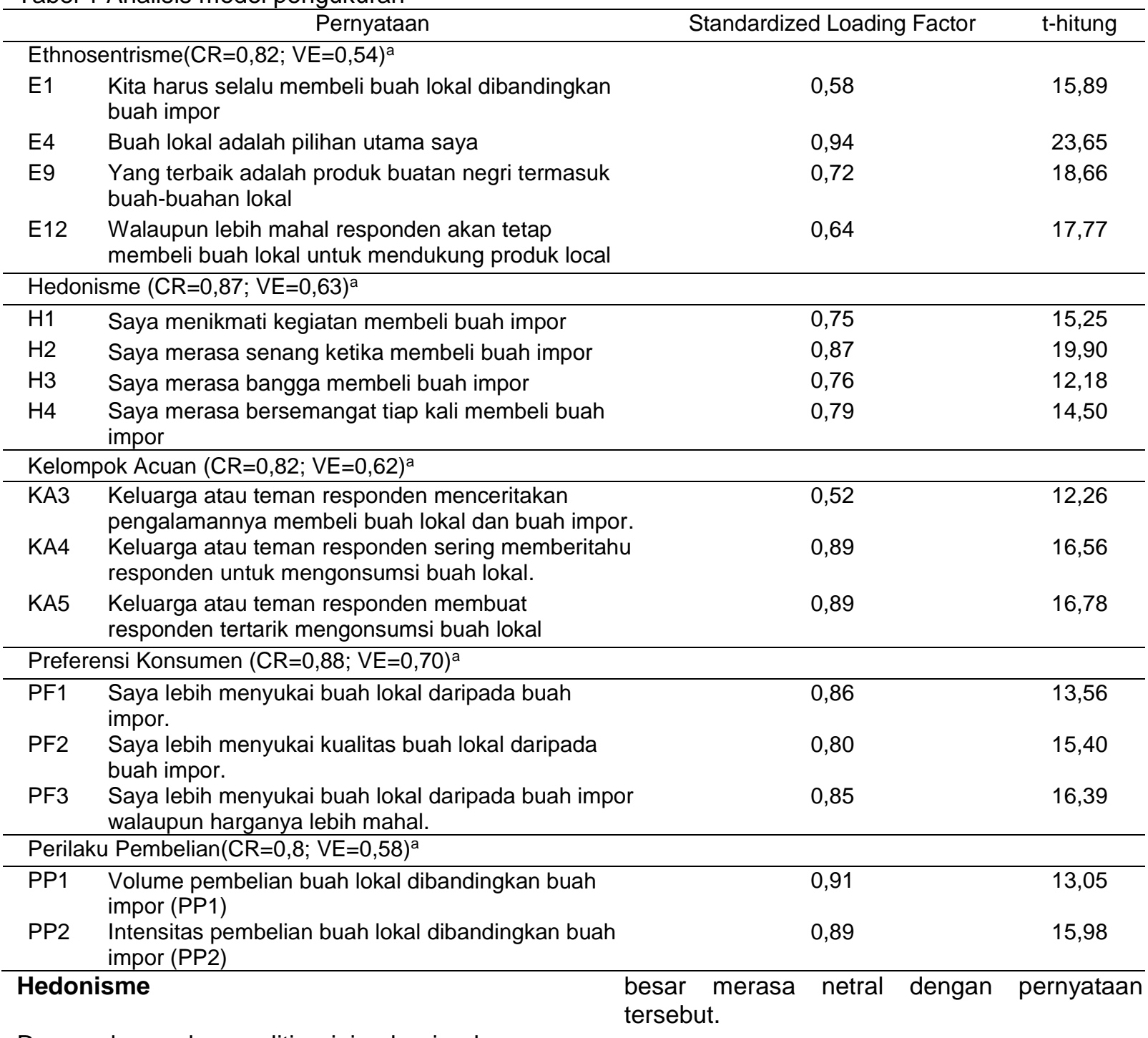

Responden pada penelitian ini sebagian besar menghabiskan waktu di luar rumah sebanyak 5 sampai 10 jam dalam satu hari selain kegiatan akademik. Indikator perilaku hedonik lainnya adalah menyukai keramaian kota yang ditunjukkan oleh proporsi terbesar responden pada penelitian ini yang mengaku menyukai keramaian kota $(51,0 \%)$. Hasil uji chi square menunjukkan bahwa terdapat hubungan antara tingkat ethnosentrisme dengan dengan perasaan bersemangat setiap kali membeli buah impor. Nilai Pearson chi-square hubungan antara ethnosentrisme dan perasaan bersemangat ketika membeli buah impor adalah 0,01 lebih kecil dari 0,05 sehingga menunjukkan adanya hubungan antara tingkat ethnosentrisme dengan perasaan bersemangat ketika membeli buah impor. Responden yang memiliki tingkat ethnosentrisme tinggi tidak merasa bersemangat setiap kali membeli buah impor, sedangkan responden dengan tingkat ethnosentrisme rendah dan sedang sebagian

\section{Faktor-faktor yang berpengaruh terhadap} preferensi dan perilaku pembelian

Uji kelayakan model (goodness of fit) dan kecocokan model pengukuran (measurement model fit). Pada penelitian ini dilakukan uji kelayakan model menggunakan 6 kriteria, yaitu Root Mean Square Error of Approximation (RMSEA), Goodness of Fit Index (GFI), Adjusted Godness of Fit Index (AGFI), Incremental Fit Index (IFI), Normed Fit Index (NFI), dan Comparative Fit Index (CFI). Hasil uji kelayakan model menunjukkan bahwa model dalam penelitian telah memenuhi syarat dan bersifat good fit sehingga model penelitian ini dikatakan layak. Uji kecocokan model pengukuran dilakukan dengan uji validitas dan reabilitas. Hasi uji validitas dan reabilitas menunjukkan bahwa model pada penelitian telah memenuhi syarat, yaitu ditunjukkan dengan nilai Variance Extracted (VE) > 0,5 
yang artinya model telah valid dan nilai Construct Reability (CR) > 0,7 yang artinya setiap konstruk laten telah valid dan reliabel (Tabel 1).

\section{Hubungan variabel laten eksogen dengan variabel indikatornya. Pada variabel laten eksogen, semua indikator yang diamati memiliki nilai uji-t di atas 1,96. Hal ini menunjukkan bahwa variabel indikator yang membentuk variabel laten eksogen pada penelitian ini memiliki pengaruh yang signifikan. Pada variabel laten eksogen ethnosentrisme, variabell indikator E4 yakni buah lokal adalah pilihan utama responden memiliki kontribusi terbesar dalam membentuk variabel laten eksogen ethnosentrisme dengan pengaruh sebesar 0,94. Pada variabel laten eksogen hedonisme, variabel indikator $\mathrm{H} 2$ yakni responden merasa senang ketika membeli buah impor memiliki kontribusi terbesar kedua dengan pengaruh sebesar 0,79 . Pada variabel laten eksogen kelompok acuan, variabel indikator yang memiliki kontribusi terbesar dalam membentuk variabel laten eksogen kelompok acuan adalah KA4 yakni keluarga atau teman responden sering memberitahu responden untuk mengonsumsi buah lokal dan KA5 yakni keluarga atau teman responden membuat responden tertarik mengonsumsi buah lokal, dengan besar pengaruh masing-masing sebesar 0,89 (Tabel $1)$.}

\footnotetext{
Hubungan variabel laten endogen dengan variabel indikatornya. Pada variabel laten endogen, semua indikator yang diamati memiliki nilai uji-t diatas 1,96. Hal ini menunjukkan bahwa variabel indikator yang membentuk variabel laten endogen pada penelitian ini memiliki pengaruh yang signifikan. Pada variabel laten endogen preferensi konsumen, variabel indikator PF1 (responden lebih menyukai buah lokal daripada buah impor) memiliki kontribusi terbesar dalam membentuk variabel laten endogen preferensi konsumen dengan pengaruh sebesar 0,86,sedangkan pada variabel laten endogen perilaku pembelian, variabel indikator PP1 (volume pembelian buah lokal dibandingkan buah impor) adalah variabel indikator dengan kontribusi terbesar dalam membentuk variabel laten endogen perilaku pembelian dengan besar pengaruh sebesar 0,95 (Tabel 1).
}

Tabel 2 Analisis model struktural

\begin{tabular}{|c|c|c|c|c|}
\hline & Standardiz & ec|t-hit| & & \\
\hline Variabel & $\begin{array}{l}\text { loading } \\
\text { factor }\end{array}$ & $\overrightarrow{1,96}$ & Kesimpulan & Square \\
\hline Etnhosentrisme $\rightarrow$ & & & & \\
\hline $\begin{array}{l}\text { Preferensi } \\
\text { Konsumen }\end{array}$ & 0,81 & $14,40^{*}$ & * Signifikan & \\
\hline Hedonisme $\rightarrow$ & & & & \\
\hline $\begin{array}{l}\text { Preferensi } \\
\text { Konsumen }\end{array}$ & $-0,12$ & $3,15^{*}$ & Signifikan & 0,72 \\
\hline Kelompok & & & & \\
\hline $\begin{array}{l}\text { Acuan } \rightarrow \\
\text { Preferensi } \\
\text { Konsumen }\end{array}$ & 0,03 & 0,60 & $\begin{array}{l}\text { Tidak } \\
\text { Signifikan }\end{array}$ & \\
\hline $\begin{array}{l}\text { Etnhosentrisme } \rightarrow \\
\text { Perilaku } \\
\text { pembelian }\end{array}$ & 0,03 & 0,43 & $\begin{array}{c}\text { Tidak } \\
\text { signifikan }\end{array}$ & \\
\hline $\begin{array}{l}\text { Hedonisme } \rightarrow \\
\text { Perilaku } \\
\text { pembelian }\end{array}$ & $-0,17$ & $4,09^{*}$ & Signifikan & \\
\hline $\begin{array}{l}\text { Kelompok } \\
\text { Aacuan } \rightarrow \\
\text { Perilaku } \\
\text { pembelian }\end{array}$ & 0,06 & 1,06 & $\begin{array}{c}\text { Tidak } \\
\text { Signifikan }\end{array}$ & \\
\hline $\begin{array}{l}\text { Preferensi } \\
\text { konsumen } \rightarrow \\
\text { Perilaku } \\
\text { Pembelian }\end{array}$ & 0,60 & $9,84^{*}$ & Signifikan & 0,46 \\
\hline
\end{tabular}

Model Struktural. Berdasarkan hasil pengolahan standardized loading factor (Tabel 2) dapat diketahui besar kontribusi yang dimiliki setiap variabel pembentuk preferensi konsumen dan perilaku pembelian. Nilai standardized loading factor yang memengaruhi preferensi konsumen yaitu ethnosentrisme sebesar 0,81, hedonisme sebesar -0,12 dan kelompok acuan sebesar 0,04. Sementara itu, nilai standardized loading factor yang memengaruhi perilaku pembelian adalah preferensi konsumen sebesar 0,60, ethnosentrisme sebesar 0,03 , hedonisme sebesar $-0,17$, dan kelompok acuan sebesar 0,06 . Hasil uji hipotesis menunjukkan bahwa ethnosentrisme dan hedonisme berpengaruh signifikan terhadap preferensi konsumen sedangkan kelompok acuan tidak berpengaruh signifikan terhadap preferensi konsumen generasi Y. Preferensi konsumen dan hedonisme berpengaruh signifikan terhadap perilaku pembelian buah lokal generasi $Y$ sedangkan ethnosentrisme dan kelompok acuan tidak berpengaruh signifikan terhadap perilaku pembelian buah lokal generasi $Y$.

Faktor ethnosentrisme memiliki pengaruh paling dominan terhadap preferensi konsumen dengan nilai faktor muatan sebesar 0,81 . Nilai $R$-square sebesar 0,72 pada variabel 
preferensi konsumen menunjukkan bahwa keragaman preferensi konsumen generasi $Y$ terhadap buah lokal dapat dijelaskan oleh model sebesar 72,0 persen sedangkan sisanya 28,0 persen dijelaskan oleh faktor lain yang tidak terdapat pada model.

Faktor preferensi konsumen memiliki pengaruh paling dominan terhadap perilaku pembelian dengan nilai loading factor sebesar 0,60 . Nilai $R$-square sebesar 0,46 pada perilaku pembelian menunjukkan bahwa keragaman perilaku pembelian konsumen generasi $\mathrm{Y}$ terhadap buah lokal dapat dijelaskan oleh model sebesar 46,0 persen sedangkan sisanya sebesar 54,0 persen dijelaskan oleh faktor lain yang tidak terdapat pada model.

\section{PEMBAHASAN}

Ethnosentrisme konsumen menggambarkan kepercayaan konsumen mengenai kepatuhan dan moralitas dalam membeli produk luar negeri (Shrimp \& Sharma, 1987). Berdasarkan hasil penelitian diketahui bahwa sebagian besar responden generasi $Y$ memiliki tingkat ethnosentrisme sedang. Hal ini menunjukkan bahwa sebagian besar konsumen generasi $Y$ yang lebih memilih untuk mengonsumsi buah impor dibandingkan buah lokal. Edu, Preda, dan Negrice (2014) menyebutkan bahwa generasi $\mathrm{Y}$ adalah konsumen yang mudah mengadopsi produk baru, apabila sebagian besar konsumen $\mathrm{Y}$ merupakan konsumen dengan tingkat ethnosentrisme sedang maka mereka dapat dengan mudah beralih dari mengonsumsi buah lokal ke mengonsumi buah impor. Buah impor memiliki tampilan yang menarik serta varian yang beragam. Hal ini dapat menyebabkan konsumen generasi $\mathrm{Y}$ lebih memilih untuk membeli dan mengonsumsi buah impor dibandingkan buah lokal.

Ethnosentrisme konsumen pada penelitian ini dapat ditunjukkan ketika konsumen menjadikan buah lokal sebagai pilihan utama dalam mengonsumsi buah-buahan. Indonesia sebagai negara agraris, harus lebih mengutamakan pilihan pada produk-produk lokal termasuk produk buah-buahan. Masuknya berbagai jenis produk buah-buahan asing membuat produk buah lokal mengalami kesulitan dalam bersaing dengan produk buah impor dikarenakan buah impor seringkali memiliki tampilan yang lebih menarik dan harga yang relatif lebih murah dibandingkan buah lokal. Oleh karena itu, penting bagi masyarakat khususnya generasi $Y$ agar menjadikan buah lokal sebagai pilihan utama untuk membantu buah lokal bersaing dengan produk buah impor tidak hanya di masa sekarang tetapi juga di masa mendatang serta diharapkan mampu menjamin keberlangsungan buah lokal di pasar buah Indonesia. Alsughayir (2013) menjelaskan bahwa etnosentrisme merupakan suatu konsep mengenai kepercayaan konsumen terhadap keunggulan produk yang dibuat oleh negaranya sendiri. Moon (2004) menjelaskan ketika etnosentrisme mengenai produk lokal semakin kuat, maka akan membuat persepsi seseorang terhadap produk lokal juga semakin tinggi.

Perilaku hedonik responden pada penelitian ini sebagian besar dilihat dari munculnya perasaan senang ketika membeli buah impor. Hal ini sesuai dengan Musriha (2011) yang mengatakan bahwa nilai hedonisme konsumen melekat pada kegiatan berbelanja sebagai kegiatan yang menyenangkan, kemudian diimbangi dengan perilaku generasi $Y$ yang lebih terpusat pada kepuasan hedonik dan pengakuan status sehingga menempatkan pertimbangan usaha dan emosi yang tinggi dalam pembelian (Edu, Preda, \& Negrice, 2014). Kegiatan belanja buah impor dapat menjadi kegiatan yang menyenangkan dikarenakan buah impor seringkali dijual di supermarket atau toko-toko buah besar ternama yang memberikan kenyamanan tempat pada saat berbelanja, tampilan rak-rak buah impor yang menarik, serta kemasan dan warna yang menarik konsumen. Kegiatan berbelanja buah di tempat seperti ini dapat memberikan kepuasan emosi bagi konsumen generasi Y. Kegiatan belanja buah di supermarket yang berlokasi di mall atau pusat perbelanjaan dapat sekaligus memberikan kesempatan bagi konsumen untuk memenuhi kebutuhan hedoniknya. Maehle et al.(2015) mengatakan bahwa banyak dari generasi $Y$ yang berpindah perilaku belanja dari belanja untuk kebutuhan objektif dan terukur menjadi belanja dengan mempertimbangkan komponen subjektif dan hedonik. Hal tersebut menyebabkan konsumen generasi $Y$ mengetahui bahwa buah lokal memiliki kualitas gizi dan vitamin yang lebih baik atau memiliki kesegaran yang lebih dibandingkan buah impor, namun melakukan pembelian buah impor karena lebih mempertimbangkan komponen hedonik dibandingkan dengan tingkat kebutuhan..

Kelompok acuan yang dapat memberikan pengaruh kepada responden adalah keluarga atau teman yang sering memberitahu dan membuat tertarik untuk mengonsumsi buah 
lokal. Generasi $Y$ lebih terhubung dan terinteraksi bila dibandingkan dengan generasi sebelumnya (Edu, Preda, \& Negrice, 2014). Kelompok acuan merupakan wadah bertukar informasi bagi konsumen. Seringnya interaksi antar konsumen generasi $Y$ juga memberikan semakin banyak informasi bagi kelompok konsumen ini. Interaksi dengan keluarga atau teman berupa ajakan untuk mengonsumsi buah lokal membuat konsumen generasi $Y$ tertarik mengonsumsi buah lokal. Preferensi responden terhadap buah lokal sebagian besar terbentuk karena kesukaan responden terhadap buah lokal walaupun harganya lebih mahal dibandingkan buah impor. Konsumen dapat lebih menyukai buah lokal dikarenakan tingkat ethnosentrisme konsumen yang tinggi sehingga konsumen selalu menjadikan buah lokal pilihan utama. Sementara itu, perilaku pembelian buah lokal oleh responden pada penelitian ini dibentuk oleh volume pembelian buah lokal tanpa mempertimbangkan intensitas pembelian buah lokal tersebut.

Ethnosentrisme memiliki pengaruh terbesar terhadap preferensi konsumen terhadap buah lokal. Semakin tinggi tingkat ethnosentrisme yang dimiliki oleh konsumen generasi $Y$ maka akan meningkatkan preferensi terhadap buah lokal. Hal ini menunjukkan bahwa dalam pendidikan konsumen untuk generasi $\mathrm{Y}$, membangun sikap cinta produk lokal (ethnosentrisme) yang dimiliki oleh konsumen generasi $Y$ merupakan hal yang penting dilakukan guna meningkatkan preferensi konsumen generasi $Y$ terhadap buah lokal secara signifikan. Apabila konsumen generasi Y lebih memilih untuk mengonsumsi buah lokal dibandingkan buah impor, maka dapat membantu buah lokal bersaing dengan buah impor di pasar buah Indonesia. Rahman, Morshed dan Hossan (2011) menyebutkan bahwa ethnosentrisme memiliki hubungan dengan karakteristik individu (usia, pendidikan dan jenis kelamin), persepsi, dan juga perilaku. Persepsi dari konsumen dalam memilih informasi yang tepat akan menentukan preferensi. Hasil penelitian Ruiz et al. (2014) menjelaskan persepsi terhadap makanan dapat memengaruhi preferensi konsumen. Hedonisme berpengaruh negatif terhadap preferensi konsumen generasi $Y$ yang berarti bahwa semakin tinggi perilaku hedonik konsumen maka preferensi terhadap buah lokal akan semakin menurun. Hasil penelitian P Ridha dan Prabowo (2015) menyebutkan bahwa hedonis berpengaruh secara parsial terhadap preferensi pembelian barang. Oleh karenanya, menekan perilaku hedonik konsumen generasi $Y$ dalam pendidikan konsumen untuk kelompok konsumen ini akan dapat meningkatkan preferensi terhadap buah lokal. Apabila konsumen generasi $Y$ dapat mengesampingkan perilaku hedonik pada saat membeli buah-buahan maka diharapkan akan lebih memilih mengonsumsi buah lokal dibandingkan buah impor.

Preferensi konsumen memiliki pengaruh terbesar bagi perilaku pembelian buah lokal konsumen generasi $Y$. Hasil penelitian menunjukkan bahwa semakin tinggi preferensi konsumen generasi $\mathrm{Y}$ terhadap buah lokal maka akan semakin banyak dan sering pula konsumen tersebut membeli buah-buahan lokal. Sementara itu, semakin tinggi perilaku hedonik konsumen generasi $Y$ maka konsumen generasi $Y$ akan semakin sedikit dan semakin jarang membeli buah-buahan lokal dibandingkan buah-buahan impor. Apabila konsumen generasi $Y$ terus mengedepankan perilaku hedoniknya maka kecil kemungkinan konsumen tersebut akan berbelanja buah lokal lebih banyak dan lebih sering dibandingkan buah impor. Hal ini dikarenakan berbelanja buah lokal tidak dapat memenuhi kebutuhan hedoniknya. Ethnosentrisme tidak berpengaruh signifikan terhadap perilaku pembelian tetapi memengaruhi secara tidak langsung melalui preferensi konsumen. Oleh karena itu, dalam pendidikan konsumen untuk generasi $\mathrm{Y}$, peningkatan preferensi konsumen kelompok ini guna meningkatkan perilaku pembelian buah lokal konsumen generasi $Y$ dapat dilakukan dengan cara meningkatkan ethnosentrisme konsumen generasi Y. Salah satu cara meningkatkan ethnosentrisme konsumen adalah melalui kampanye terhadap produk lokal. Penelitian oleh Salehudin (2016) mengenai kegiatan kampanye oleh pemerintah mengenai produk lokal menunjukkan bahwa kegiatan kampanye "beli lokal" dapat meningkatkan ethnosentrisme konsumen. Konsumen generasi $Y$ adalah konsumen yang dikendalikan oleh keinginan untuk memiliki citra sosial yang trendi (Twenge \& Campbell, 2008) sehingga kegiatan kampanye untuk menjadikan tren konsumsi produk lokal dapat diterapkan bagi konsumen generasi $Y$.

\section{SIMPULAN DAN SARAN}

Tingkat ethnosentrisme konsumen generasi $Y$ sebagian besar berada pada tingkat ethnosentrisme sedang. Responden menyukai buah lokal tetapi dapat dengan mudah mengonsumsi buah impor apabila buah lokal yang diinginkan tidak tersedia atau dikarenakan beberapa pertimbangan lainnya. 
Ethnosentrisme berpengaruh positif terhadap preferensi konsumen generasi $Y$ terhadap buah lokal. Semakin tinggi tingkat ethnosentrisme konsumen maka semakin tinggi juga preferensinya terhadap buah lokal. Hedonisme berpengaruh negatif terhadap preferensi konsumen generasi $Y$ terhadap buah lokal. Semakin tinggi perilaku hedonic konsumen maka semakin rendah preferensinya terhadap buah lokal. Ethnosentrisme berpengaruh paling besar terhadap preferensi konsumen generasi $Y$ terhadap buah lokal. Preferensi konsumen berpengaruh positif dan memiliki pengaruh paling besar terhadap perilaku pembelian buah lokal konsumen generasi $Y$. Semakin tinggi preferensi konsumen generasi $Y$ terhadap buah lokal maka konsumen generasi $Y$ akan semakin banyak dan sering membeli buah lokal tersebut. Hedonisme berpengaruh negatif terhadap perilaku pembelian buah lokal konsumen generasi Y. Semakin tinggi perilaku hedonik konsumen generasi $Y$ maka akan semakin sedikit dan jarang konsumen generasi $Y$ tersebut membeli buah lokal. Oleh karenanya, dalam pendidikan konsumen untuk generasi $Y$, meningkatkan preferensi konsumen generasi $Y$ terhadap buah lokal dapat dilakukan dengan cara meningkatkan ethnosentrisme konsumen generasi $Y$ sedangkan meningkatkan perilaku pembelian buah lokal generasi $Y$ dapat dilakukan dengan cara meningkatkan preferensi konsumen generasi $Y$ terhadap buah lokal. Hasil penelitian mengindikasikan bahwa menekan hedonisme dapat meningkatkan preferensi dan perilaku pembelian buah lokal konsumen generasi $\mathrm{Y}$.

Saran yang dapat diberikan berdasarkan hasil penelitian adalah perlunya peran dari pemerintah untuk meningkatkan ethnosentrisme. Peran tersebut dapat berupa kampanye atau sosialisasi untuk mengajak masyarakat mencintai produk lokal. Adanya program revolusi mental terhadap konsumen Indonesia perlu diberlakukan lebih spesifik disesuaikan dengan segmen pasar dan jenis konsumen. Program revolusi mental adalah program yang dapat membentuk mental konsumen Indonesia untuk lebih mencintai produk lokal demi mendukung ekonomi negaranya. Bentuk program tersebut dapat berupa sosialisasi cinta produk lokal dapat dilakukan melalui kampanye langsung ke masyarakat dan juga melalui pendidikan konsumen baik secara formal maupun informal. Peningkatan fasilitas pasar tradisional dan penataan rak penjualan buah lokal juga dapat dilakukan untuk memenuhi kebutuhan hedonik konsumen melalui berbelanja buah lokal. Pemerintah juga dapat menghimbau supermarket atau pasar modern untuk menjual produk lokal secara proporsional dan memberikan insentif bagi supermarket atau pasar modern yang mendukung produk lokal melalui penjualannya. Pada penelitian selanjutnya, sebaiknya dilakukan penelitian terhadap generasi $Y$ dengan ruang lingkup yang lebih luas dan menggunakan variabel yang lebih beragam yang belum terdapat pada penelitian ini. Ruang lingkup dan variabel yang lebih beragam diharapkan mampu meningkatkan kemampuan model untuk menjelaskan preferensi dan perilaku pembelian buah lokal generasi $Y$ lebih detail dan mendalam.

\section{DAFTAR PUSTAKA}

[hortikultura pertanian]. 2013. Judul [Kementrian Pertanian Pusat Data dan Sistem Informasi Impor Komoditi Pertanian Subsektor Hortikultura (Segar)]. [diacu 2017 Januari 18]. Tersedia pada: http://aplikasi.pertanian.go.id/eksim2013 /hasilimporSubsek.asp

Aerkens, J., Verbeke, W., Mondelaers, k., \& Haylenbroeck, G., V. (2009). Personal determinants of organic food consumption: a review. British Food Journal, 111(10): 1140-1167.

Alsughayir, A. (2013). Consumer ethnocentrism: a literature review. International Journal of Business and Management Invention. 2(5): 50-54

Amri, I.S. (2015). MEA, peluang bersyarat. Masyarakat Ekonomi ASEAN 2015. 7 (Maret) : 4-5

Anggasari, P., Yuliati L., N., \& Retnaningsih. (2013). Pengaruh ethnosentrisme terhadap sikap, preferensi, dan perilaku pembelian buah lokal dan impor. Jurnal Manajemen dan Agribisnis. 10(2): 128136.

Anoraga, B., J., \& Iriani, S., S. (2013). Pengaruh gaya hidup dan kelompok acuan terhadap keputusan pembelian smartphone merek samsung galaxy. Jurnal IImu Manajemen. 1(4): 985-995.

Bakewell, C., \& Mitchell, V., W. (2003). Generation $Y$ female consumer decision making styles. International Journal of Retail and Distribution Management. 31(2): 95-106. 
Bappenas. (2017). Strategi nasional perlindugan konsumen. Presentasi disampaikan dalam Forum Sinkronisasi Kebijakan Bidang PKTN pada tanggal 18 September 2017 di Jakarta

Benny, G., Abdullah, K. (2011). Indonesian perceptions and attitudes toward the ASEAN Community. Journal of Current Southeast Asian Affairs. 30:39-67.

Bianchi, C. \& Mortimer, G. (2015). Drivers of local food consumption: a comparative study. British Food Journal, 117(9): 2282-2299.

Eastman, J., \& liu, J. (2012). The impact of generational cohorts on status consumption: an exploratory look at generational cohort and demographics on status consumption. Journal of Consumer Marketing. 29(2): 93-102.

Edu, T., Preda, O., \& Negrice, I. C. (2014). Fashion consumer behavior patterns promted by the youngest layer of generation $Y$ evidence from romania. Industria Textila. 65(6): 349-357.

Engel, J., F., Blackwell R., D., \& Miniard P., W. (1994). Perilaku Konsumen. Budijianto, penerjemah. Jakarta(ID): Binarupa Aksara.

European Commission. (2011). Consumer Empowerment in the EU: Commission Staff Working Paper, pages 1 and 2.

Fernandez, P. (2009). Impact of branding gen Y's choice of clothing. Journal of the South East Asia Research. 1(1): 79-95.

Filho, E., J., M., A., \& Dholakia, R., R. (2013). Hedonism as a decision factor and technologic usage. Review of Business Management. 15(48): 343-361.

Gursoy, D., Maier, T., A., \& Chi, C., G. (2008). Generational differences: an examination of work, values, and generational gaps in the hospitality workface. International Journal of Hospitality Management, 27(3): 448-458

Hammerl, M., Doiner, F., Foscht, T., \& Brandsatter, M. (2016). Attribution of symbolic brand meaning: the interplay of consumers, brands, and reference group. Journal of Consumer Marketing. 33(1):32-40.

Hsu, J., L., \& Nien, H., P. (2008). Who are ethnocentric? examining consumer ethnocentrism in chinese societies. Journal of Consumer Behavior, 7(20): 436-447.
Hyllegard, K., Yan R., Ogle, J., \& Attmann, J. (2011). The influence of gender, social cause, charitable support, and message appeal on Gen Y's responses to causerelated marketing. Journal of Marketing Management. 27(2): 100-123.

Japarianto, E. (2011). Pengaruh shopping life style dan fashion involvement terhadap impulse buying behavior masyarakat high income surabaya. Jurnal Manajemen Pemasaran. 6(1): 32-41.

Lazarevic, V. (2012). Encouraging brand loyalty in fickle generation $Y$ consumers. Young Consumers. 13(1): 45-61.

Li, X., Yang, J., Wang, X., \& Lei, D. (2012). The impact of country-of-origin image, consumer ethnocentrism and animosity on purchase intention. Journal of Software. 7(10).

Lin, Y., L., \& Chenn, Y., W. (2009). A study on the influence of purchase intentions on repurchase decisions: the moderating effercts of reference groups and perceived risks. Tourism Review. 6(3): 24-28.

Loroz, P., S., \& Helgeson, J., G. (2013). Boomers and their babies: an exploratory study comparing psychological profiles and advertising appeal effectiveness across two generations. Journal of Marketing Theory and Practice. 21(3):289-306.

Maehle, N., Iversen, N., Hern, L., \& Otnes, C. (2015). Exploring consumer preference for hedonic and utilitarian food attributes. British Food Journal. 117(12): 30393063.

Malau, M.T. (2014). Aspek hukum peraturan dan kebijakan pemerintah Indonesia menghadapi liberalisasi ekonomi regional. Masyarakat Ekonomi ASEAN 2015. 3:2.

Mendag. (2013). Siaran Pers: Mencintai Produk Lokal Kunci Kesejahteraan Indonesia. Disampaikan pada tanggal 10 Mei 2013, di Pontianak.

Meriac, J., P., Woehr, D., J., \& Banister, C. (2010). Generational differences in work ethic: an examination of meaurement equivalence across three cohorts. Journal of Business Psychology. 25(2): 315-324.

Moon, B.J. (2004). Ethnosentrism and product knowledge on consumers' utilization of 
country-of-origin information. Advances in Consumer Research. 31:667-673.

Musriha. (2011). Pengaruh perilaku pembelian hedonic dan utilitarian terhadap store loyalty di Matahari Departement Store Surabaya. Jurnal Ekonomika. 4(1): 1218.

Orth, U., R., \& Kahle, L., R. (2008). Interpersonal variation in consumer susceptibility to onormative influence: toward a better understanding of brand choice decisions. The Journal of Social Psychologi. 148(4): 423-447.

P Ridha, R.R., \& Prabowo, F. S.A. (2015). Pengaruh motivasi belanja utilitarian dan hedonis terhadap preferensi pembelian online pada Line Shopping. EProceeding of Management, 2 (3):1-6

Pantecost, R., \& Andrew, L. (2010). Fashion retailing and the bottom line: the effects of generational cohorts, gender, fashion fanship, attitudes, and impulse buying on fashion expenditure. Journal of Retailing and Consumer Services. 17(1): 43-52.

Qing, P., Lobo, A., \& Chongguang, L. (2012). The impact of lifestyle and ethnocentrism on consumer's purchase intentions of fresh fruit in China. Journal of Consumer Marketing. 29(1): 43-51.

Rahman, H.M., Morshed, M, Hossan, M.T. (2011). Identifying and measuring consumer ethnocentric tendencies in Bangladesh. World Review of Business Research. 1(1):71-89.

Rhiney, E. (2011). Consumer ethnocentrism: the effect of threat, foreigness, and heritage brands (Disertasi). University in Partial Fullfilment of the Requirements, Saint Louis.

Ruiz, N.R.M., Díaz, J.A.L., Medrano, A.W., Castro, J.A.J., \& Angulo, O. (2014). Oral fat perception is related with body mass index, preference and consumption of high-fat foods. Physiology and Behavior. 129:36-42
Salehudin, I. (2016). 100\% love indonesia: role of government campaign to promote local products in indonesoa. Asean Marketing Journal. 7(1): 1-17.

Satriawan, S., B., Hartoyo \& Yuliati L., N. (2015). Hedonisme konsumen sebagai variabel mediator antara pemasaran dan pembelian tidak terencana. Jurnal IImu Keluarga dan Konsumen. 8(1): 59-68.

Schifmann, L., G., \& Kanuk, L., L. (2010). Consumer Behavior. New Jersey: Prentice Hall.

Shrimp, T., \& Sharma, S. (1987). Consumer ethnocentrism: construction and validation of the CETSCALE. Journal of Marketing Research. 24: 280-289.

Simanjutak, M. (2014). Tingkat keberdayaan dan strategi pemberdayaan konsumen. (Disertasi). Institut Pertanian Bogor, Bogor, Indonesia

Sukmaningtyas, A., \& Hartoyo. (2013). Pengaruh nilai dan gaya hidup terhadap preferensi dan perilaku pembelian buahbuahan impor. Jurnal Ilmu Keluarga dan Konsumen. 6(1): 39-48.

Sumarwan, U. (2014). Perilaku Konsumen: Teori dan Penerapannya dalam Pemasaran. Bogor (ID): Penerbit Ghalia Indonesia.

Swajaya, N. (2015). MEA perlukah kita takutkan?. Masyarakat Ekonomi ASEAN 2015. 7 (Maret) :12-13

Twenge, J., M., \& Campbell, S., M. (2008). Generational differences in psychological traits and their impact on the workplace. Journal of Management Psychology. 23(8): 862-877.

William, K., C., \& Page, R., A. (2011). Marketing to the generations. Journal of Behavioral Studises in Business, 3(1): 37-53. 